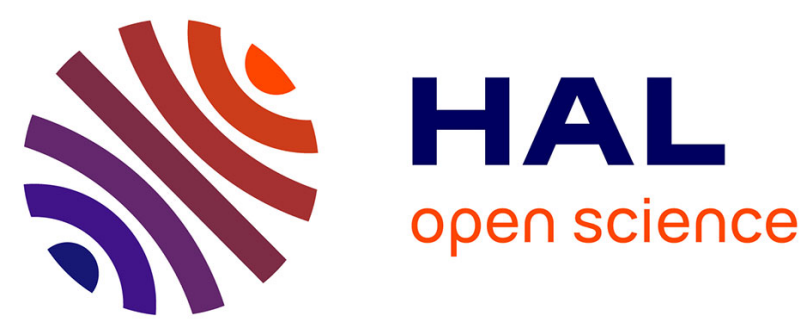

\title{
S-DLCAM: A Self-Design and Learning Cooperative Agent Model for Adaptive Multi-Agent Systems
}

Wafa Mefteh, Frédéric Migeon, Marie-Pierre Gleizes, Faiez Gargouri

\section{To cite this version:}

Wafa Mefteh, Frédéric Migeon, Marie-Pierre Gleizes, Faiez Gargouri. S-DLCAM: A Self-Design and Learning Cooperative Agent Model for Adaptive Multi-Agent Systems. 22nd Workshops on Enabling Technologies: Infrastructure for Collaborative Enterprises @ WETICE 2013, Jun 2013, Hammamet, Tunisia. pp.39-41, 10.1109/WETICE.2013.58 . hal-01148192

\section{HAL Id: hal-01148192 https://hal.science/hal-01148192}

Submitted on 4 May 2015

HAL is a multi-disciplinary open access archive for the deposit and dissemination of scientific research documents, whether they are published or not. The documents may come from teaching and research institutions in France or abroad, or from public or private research centers.
L'archive ouverte pluridisciplinaire HAL, est destinée au dépôt et à la diffusion de documents scientifiques de niveau recherche, publiés ou non, émanant des établissements d'enseignement et de recherche français ou étrangers, des laboratoires publics ou privés. 


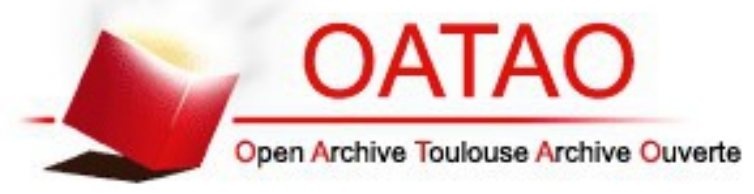

\section{Open Archive TOULOUSE Archive Ouverte (OATAO)}

OATAO is an open access repository that collects the work of Toulouse researchers and makes it freely available over the web where possible.

This is an author-deposited version published in : http://oatao.univ-toulouse.fr/ Eprints ID : 12478

To link to this article : DOI :10.1109/WETICE.2013.58

URL : http://dx.doi.org/10.1109/WETICE.2013.58

To cite this version : Mefteh, Wafa and Migeon, Frédéric and Gleizes, Marie-Pierre and Gargouri, Faiez S-DLCAM: A Self-Design and Learning Cooperative Agent Model for Adaptive Multi-Agent Systems. (2013) In: IEEE International Conference on Collaboration

Technologies and Infrastructures - WETICE 2013, 17 June 2013 - 20 June 2013 (Hammamet, Tunisia).

Any correspondance concerning this service should be sent to the repository administrator: staff-oatao@,listes-diff.inp-toulouse.fr 


\title{
S-DLCAM: A Self-Design and Learning Cooperative Agent Model for Adaptive Multi-Agent Systems
}

\author{
Wafa MEFTEH ${ }^{*, * *}$, Frédéric $M I G E O N^{*}$, Marie-Pierre GLEIZES $S^{*}$, and Faiez GARGOURI** \\ *University of Paul Sabatier, IRIT, 118 Route de Narbonne, 31062 Toulouse, Cedex 9, France \\ (mefteh, migeon, gleizes)@irit.fr \\ **University of Sfax, MIRACL, Pôle Technologique de Sfax BP 242, 3021, Sakiet Ezzit Sfax. TUNISIE. \\ (faiez.gargouri@fsegs.rnu.tn), (wafa.mefteh07@gmail.com)
}

\begin{abstract}
Given the incomplete knowledge that an Adaptive Multi Agent System (AMAS) has on its dynamic environment, the detection and the correction of problems encountered called Non Cooperative Situations for the construction of the good behaviour of the AMAS agent can challenge even the most experienced designer. Our goal is to help the AMAS designer in his task by providing an agent behaviour able to self-design. In this paper, we propose a self-design and learning cooperative agent model.
\end{abstract}

Keywords-Adaptive Multi-Agent Systems; Cooperative Agent; Self-Design and Learning Cooperative Agent Model.

\section{INTRODUCTION}

For Adaptive Multi-Agent System (AMAS) [1], the development of adaptation implies the need to focus on the agent level. This is to give the agent the means to decide autonomously to change its relationships with other agents in order to move toward a cooperative organization. Thus, depending on the interactions that the AMAS has with its environment, the organization between its agents emerges. Building such self-organized systems is not a trivial task. In this paper, we propose a new cooperative agent model based on Self-Design and learning mechanisms developed from the agent model associated with the AMAS theory [1], [2], [3]. We take in account the following important works: [4] (in which Capera et al. present a model based upon a sort of extended automata product, dedicated to multi-agent systems) and [5] (in which Russel and Norvig present how an agent can find a sequence of actions that achieves its goals, when no single action will do). Indeed, we consider that the Self-Design and Learning Cooperative Agent (S-DLCA) life cycle goes through two levels: the preliminary level (PL) (nominal and cooperative behaviour) given by the designer and the heigh level (HL) which is responsible of the detection and correction of the Non Cooperative Situations (NCS) that the agent may encounter during its life. This model was developed under SeSAm (http://www.simsesam.de/) and it can be used by any AMAS designer in order to help him in the detection and correction of the NCS using the new ADELFE methodology extensions [6].

\section{Redefinition AND LOCATION OF the NON Cooperative Situations in the AGent Life CyCle}

We consider that the agent life-cycle goes throw three phases: Perception \& Interpretation $(P \& I)$, Reasoning \& Decision $(R \& D)$ and Communication \& Action $(C \& A)$. We identify new types of Non Cooperative Situations that an AMAS agent may encounter and we locate them with the old ones in the agent life cycle (Table I).

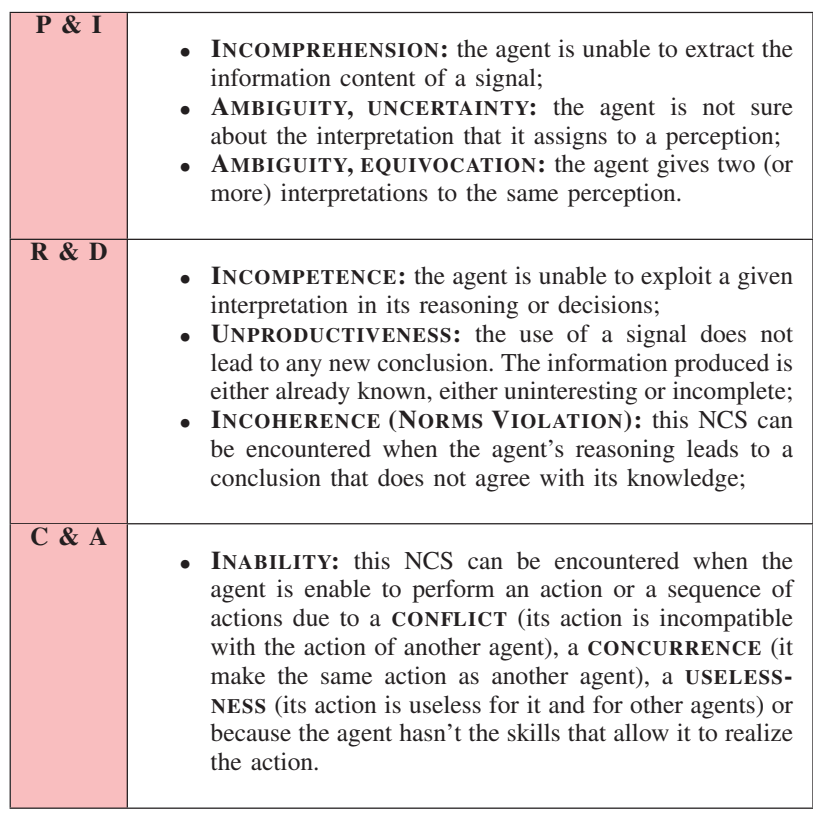

Table I

REDIFINITION AND LOCATION OF THE NCS IN THE AGENT LIFE-CYCLE

\section{THE STATIC STRUCTURE OF THE PROPOSED AGENT MODEL}

Figure 1 presents the static view of our agent model and its different modules are defined in table II. 


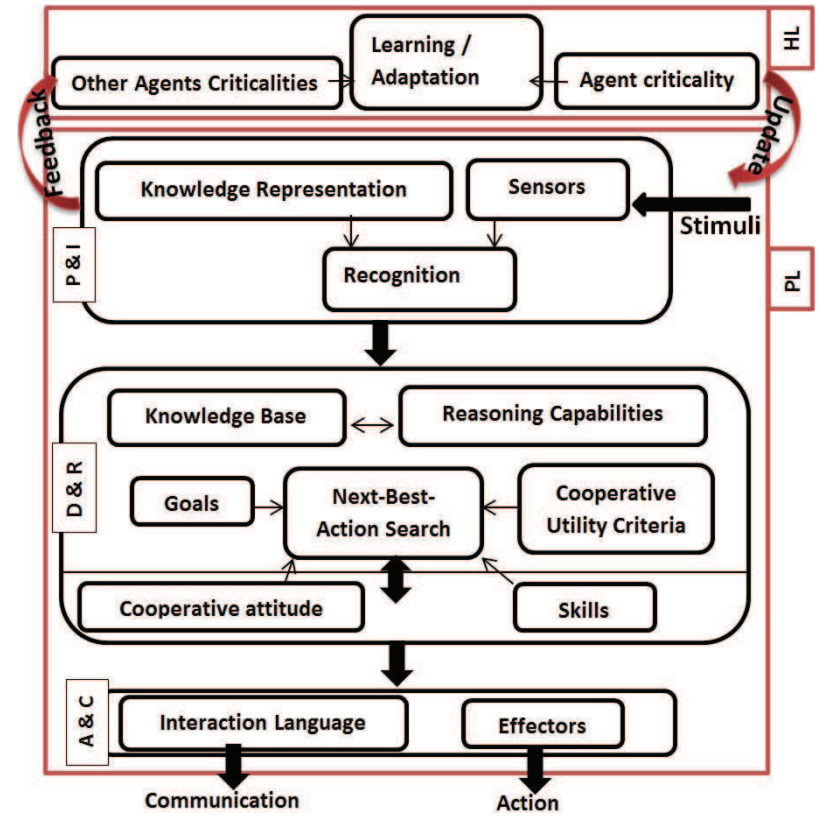

Figure 1. The static view of the Self-design and Learning Cooperative Agent.

\begin{tabular}{|c|c|}
\hline Sensors & This module enables the agent to sense its environment. \\
\hline $\begin{array}{l}\text { Knowledges } \\
\text { Representa- } \\
\text { tion }\end{array}$ & $\begin{array}{l}\text { This module represents The language of representation } \\
\text { used by the designer to represent the agent's knowl- } \\
\text { edges. }\end{array}$ \\
\hline Recognition & $\begin{array}{l}\text { This module enables the agent to recognize/interpret } \\
\text { what it perceives. }\end{array}$ \\
\hline $\begin{array}{l}\text { Knowledge } \\
\text { Base }\end{array}$ & $\begin{array}{l}\text { This module represents the agent's knowledge about } \\
\text { itself and its environment. }\end{array}$ \\
\hline $\begin{array}{l}\text { Reasoning } \\
\text { Capabilities }\end{array}$ & $\begin{array}{l}\text { This module is given by the designer in order for } \\
\text { the agent to reason on its interpretations using its } \\
\text { knowledges. }\end{array}$ \\
\hline Goals & $\begin{array}{l}\text { This module represents the local goal that the agent } \\
\text { must achieve in the form of a future agent state. }\end{array}$ \\
\hline Skills & $\begin{array}{l}\text { This module represents the atomic actions and the } \\
\text { sequences of actions that the agent can perform. }\end{array}$ \\
\hline $\begin{array}{l}\text { Cooperative } \\
\text { Utility } \\
\text { Criteria }\end{array}$ & $\begin{array}{l}\text { This module is responsible for the utility measurement } \\
\text { of an agent state. It allows the agent to choose between } \\
\text { different future states that can lead to its objective. }\end{array}$ \\
\hline $\begin{array}{l}\text { Next-Best- } \\
\text { Action } \\
\text { Search }\end{array}$ & $\begin{array}{l}\text { This module is responsible for searching for the best } \\
\text { next action to decide. The next best action is decided } \\
\text { cooperatively. }\end{array}$ \\
\hline $\begin{array}{l}\text { Cooperative } \\
\text { attitude }\end{array}$ & $\begin{array}{l}\text { This module represents how the agent must behave to } \\
\text { realize a good cooperation with other agents and its } \\
\text { environment. }\end{array}$ \\
\hline $\begin{array}{l}\text { Interaction } \\
\text { Language }\end{array}$ & $\begin{array}{l}\text { This module represents the protocols used by the agent } \\
\text { to interact with other agents. }\end{array}$ \\
\hline Effectors & $\begin{array}{l}\text { This module enables to the agent to realize a desired } \\
\text { action. }\end{array}$ \\
\hline $\begin{array}{l}\text { Other } \\
\text { Agents } \\
\text { Criticalities }\end{array}$ & $\begin{array}{l}\text { This module support the criticalities of the other agents. } \\
\text { The agent must behave in the way that permits it to } \\
\text { equilibrate the criticalities of the other agents. }\end{array}$ \\
\hline $\begin{array}{l}\text { Learning / } \\
\text { Adaptation }\end{array}$ & $\begin{array}{l}\text { This module is responsible for the learning of the agent } \\
\text { in order for it to adapt to its environment and achieve } \\
\text { the functional adequacy of the system. }\end{array}$ \\
\hline $\begin{array}{l}\text { Agent criti- } \\
\text { cality }\end{array}$ & $\begin{array}{l}\text { The agent must behave in the way that permits it to } \\
\text { equilibrate its local criticality. }\end{array}$ \\
\hline
\end{tabular}

DEFINITION OF THE AGENT MODULES

\section{THE DYNAMIC BEHAVIOUR OF THE PROPOSED AGENT MODEL}

The agent perceives its environment and stores its perceptions in the list of perceptions $\left(L_{p}\right)$. It gives interpretations about these perceptions and stores them in the list of interpretations $\left(L_{i}\right)$. It connects each perception " $p$ " with the predicates "pr" it knows and likely to be perceived. $D_{c}(p, i)$ represents the degree of certainty of the interpretation given to this perception. Algorithm 1 presents how the agent can detect an NCS related to the first phase $\left(N C S_{p}\right)$. Then, the

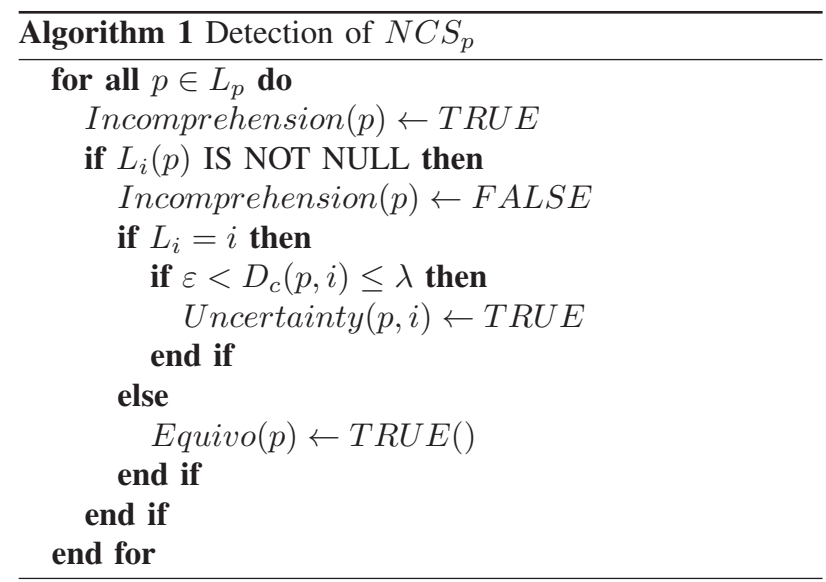

agent reasons on the $L_{i}$ using its Knowledge Base $\left(K_{b}\right)$. It gives conclusions which are stored in the list of conclusions $\left(L_{c}\right)$ and it decides what activities to perform and save them in the list of decisions $\left(L_{d}\right)$ and finally schedules them and stores them in the list of scheduled activities $\left(L_{s a}\right)$. Algorithm 2 illustrates the detection of the NCS related to the second phase $\left(N C S_{r}\right)$. It is an INCOMPETENCE when an interpretation " $i$ " is not used to produce any conclusion or to make any decision. It is an Unproductiveness when the

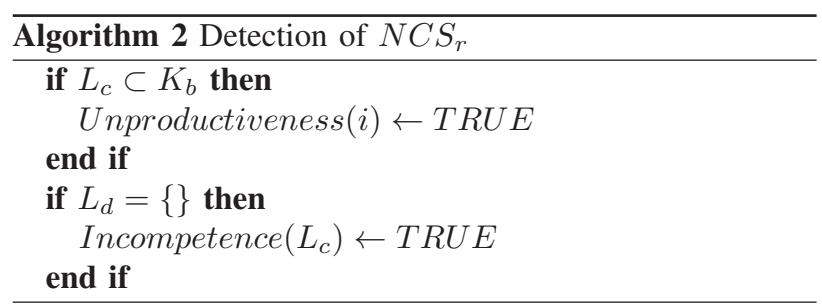

given conclusion already exists in $K_{b}$. It is an Incoherence when the given conclusion breaks one or more agent's rules. Finally, it performs activities elaborated in the R \& D phase and saves each performed action in the list of performed actions $\left(L_{p a}\right)$. Algorithm 3 illustrates the detection of the NCS related to the third phase $\left(N C S_{a}\right)$. A decided activity is not performed because there is a Conflict and/or a Concurrence and/or a Uselessness and/or the agent hasn't the skills that enable it to perform this activity. It is a Conflict 


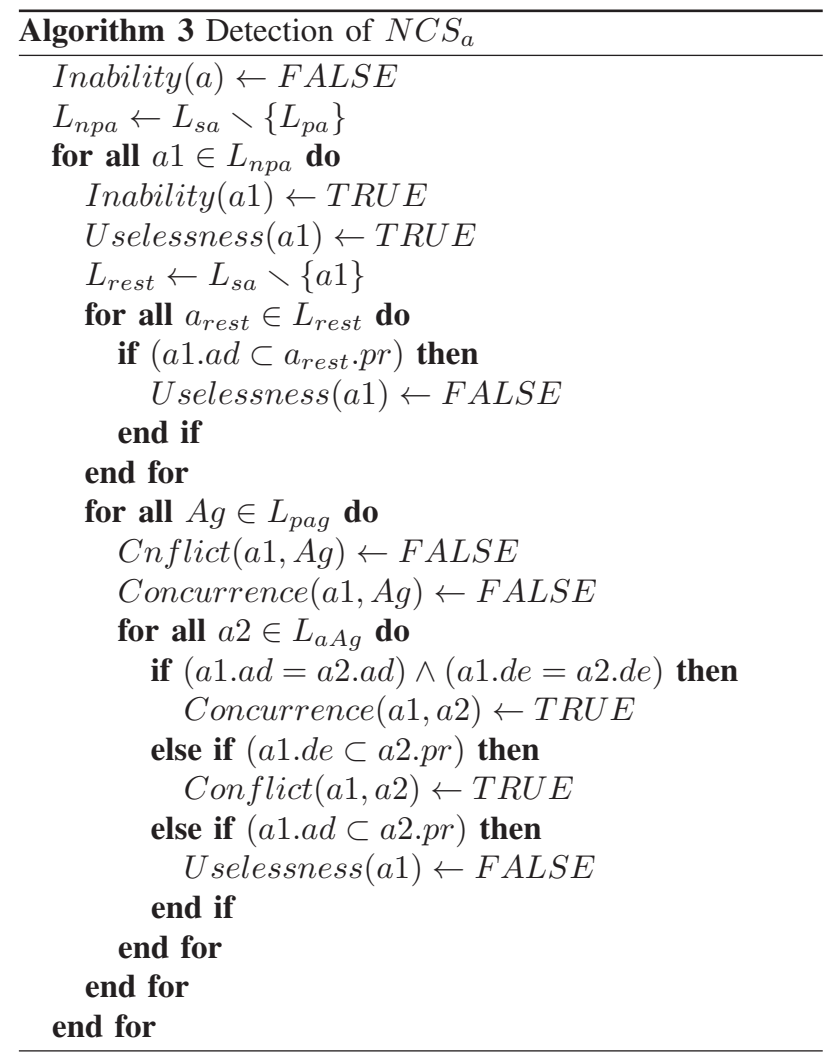

if the deletions made by the execution of an action (al.de) contain preconditions of a perceived agent's action (a2.pc). The perceived agents are stored in the list of perceived agents $\left(L_{\text {pag }}\right)$. The actions to be made by a perceived agent "Ag" are saved in the list of actions to be performed by a perceived agent $\left(L_{a A g}\right)$. It is a Concurrence if all of the agent's action additions (al.ad) (and respectively all deletions (al.de) are among the additions $(a 2 . a d)$ (respectively deletions (a2.de) of a perceived agent's actions. It is a Uselessness when the additions made by the agent's action (al.ad) are not part of the preconditions of its other actions $L_{a 1 . p c}$ nor the preconditions of perceived agent's actions $L_{a 2 . p c}$.

To deal with the encountered NCS, the agent realizes a set of specific actions to go out from each type of NCS. For the Conflict, Concurrence and Uselessness, the agent can anticipate them if possible since the R \& D phase. For each encountered NCS, the agent tries to follow the following actions:

- $\alpha$ : Relate the current situation to other previous situations based on its experience in order to find a way to correct the current situation.

- $\beta:$ : if $\rceil \alpha \Longrightarrow$ it tries to ask the perceived agents if they can help it.

- $\delta$ : if $\rceil \beta \Longrightarrow$ it asks the designer to improve his work by giving more examples (for an $N C S_{p}$ ), enhancing the reasoning capabilities and the knowledge base (for an $N C S_{r}$ ) or enhancing the skills (for an $N C S_{a}$ )

We propose that the agent operates in two modes: the "Experimentation Mode" and the "Deployment Mode". During the "Experimentation Mode", when detecting a NCS, the agent can ask the designer if it can find a solution for it. When a correction of a NCS occurrence is proposed to the agent, it learns from this in order to avoid it the next time. After many executions, the agent should be able, during the Deployment Mode, to correct by itself the encountered NCS based on its learning from the many corrections made during the "Experimentation Mode".

\section{CONCLUSION}

In this paper, we provide a new cooperative agent model for Adaptive Multi Agent Systems. This model is based on learning mechanisms to give the agent the ability to selfdesign. Our objective is to help the designer and facilitate his task by automating as much as possible the task of detection and correction of the Non Cooperative Situations.

\section{REFERENCES}

[1] J.-P. Georgé, M. P. Gleizes, and P. Glize, "Conception de systèmes adaptatifs à fonctionnalité émergente: la théorie des AMAS," Revue d'Intelligence Artificielle, vol. 17, no. 4/2003, pp. 591-626, 2003.

[2] N. Daures, "Etude de la simulation de systèmes multiagents pour la conception vivante d'agents dans la méthode ADELFE," Université Paul Sabatier, Toulouse, France, Rapport de Master Master Recherche IARCL, June 2006.

[3] S. Lemouzy, "Auto-ordonnancement coopératif de règles comportementales," Université Paul Sabatier, Toulouse, France, Rapport de Master, June 2007.

[4] D. Capera, J. Fanchon, J.-P. Georgé, and V. Camps, "A Generic Model Based on Automata for Multi-Agent Systems," in European Workshop on Multi-Agent Systems (EUMAS), Brussels, Belgium, 06/12/2005-08/12/2005. http://www.kvab.be: The Royal Flemish Academy of Belgium (KVAB), Dcember 2005, pp. 79-90.

[5] R. Stuart and N. Peter, Artificial Intelligence - A Modern Approach (3. internat.ed.). Pearson Education, 2010.

[6] W. Mefteh, F. Migeon, M. P. Gleizes, and F. Gargouri, "Simulation Based Design for Adaptive Multi-Agent System: Extensions to the ADELFE methodology," in WETICE 2013 Conference, 11th Adaptive Computing (and Agents) for Enhanced Collaboration (ACEC), Hammamet, Tunisie, 17/06/2013-20/06/2013. IEEE. 